\title{
Does government policy and company size influence stakeholders' perception on the adoption of International Financial Reporting Standards (IFRS) in Nigeria?
}

\author{
Augustine Ayuba, Benjamin Kumai Gugong \\ Department of Accounting, Faculty of Social and Management Sciences, Kaduna State University, PMB, 2339, Kaduna, Nigeria
}

Email address:

ayubaaugustine@yahoo.com (A. Ayuba)

To cite this article:

Augustine Ayuba, Benjamin Kumai Gugong. Does Government Policy and Company Size Influenced Stakeholders Perception on the Adoption of International Financial Reporting Standards (IFRS) in Nigeria. International Journal of Economics, Finance and Management Sciences. Vol. 2, No. 4, 2014, pp. 257-262. doi: 10.11648/j.ijefm.20140204.14

\begin{abstract}
This study examines some factors influencing the adoption of International Financial Reporting Standards (IFRS) among the various stakeholders in Nigeria. A research model was developed to indicate the relationship between government policy and company size that were argued to have a positive significant relationship on the adoption of IFRS. This study is based on survey design; after successful reliability tests, correlation and multiple regression were used in analyzing the data. Results indicate that, government policy has a positive significant relationship with the adoption of IFRS, while company size was found to be insignificant with the adoption of IFRS. The study recommends that, company size should be properly taken into consideration either in terms of small, medium or large size in order to ensure a smooth transition from Nigerian Generally Accepted Accounting Principles to full adoption of IFRS in the country.
\end{abstract}

Keywords: Government Policy, Company Size, International Financial Reporting Standards,

Nigerian Generally Accepted Accounting Principles

\section{Introduction}

Most countries world-wide have resorted to pursuing the same objective, when it comes to the welfare of their economy. This is possible because, it has enhanced their dynamic global market. This aim is mainly pursued by developing countries more than other countries. Globalization has played a key role in this manner by dissolving the boundaries between countries and financial markets. Similarly, the increase in multinational companies' activities, economic co-operations and political unifications among developed countries are increasing the efforts of developing countries to be part of this global market, which will require transparent financial information (alp \& Ustundag, 2009). Therefore, economic and political factors have contributed to the sudden rush of the international community's to converge on their nations' Generally Accepted Accounting Principles (GAAP) with the International Financial Reporting standards (IFRS) (Fontes, Alexandra, Rodrigues \& Russell, 2005). This indicates the power and pervasive nature of globalization (Neu \& Ocampo, 2007), and has resulted in the institutionalization of a new regulatory regime. Thus, domestic economies have become increasingly vulnerable to the external shocks caused by an expanding world economy and therefore necessitating the adoption of globalized practices if they are to function effectively (Lehman, 2005). Nigeria is a country that is characterized by various institutional interest groups that play a substantial role in the adoption of IFRS. One of these interest groups is the legal framework, which is characterized by a plethora of laws and regulations that provide the legal basis for accounting and financial practices in Nigeria. However, the main legal framework for corporate reporting and auditing practice is the companies and allied matters act (2004). As noted, Iyoha and Oyerinde (2010) pointed that, Nigeria does not lack the required legal backing for her financial transactions. In the same vein, Okaro (2004) observed that, the challenge with Nigerian legal frameworks is in the archaic nature of the financial rules and regulations in force. The position of Okaro, is further reinforced by the assertion of Iyoha and Oyerinde, which suggests that Nigerian laws suffer from severe weakness in enforcement, compliance and regulation. This weakness was noted by the World Bank (2004) which observed that the process of 
adjudication in cases in Nigerian court is so slow that regulators are discouraged from seeking support from the courts and law enforcement agencies in enforcing sanctions. The world bank further observed that, the Nigerian accounting standard board (NASB now the financial reporting council of Nigeria (FRCN)) lacks adequate resources to fulfil its mandate. As a government agency, the NASB has relied on government subventions and has been exposed to serious budgetary constraints that hinder its performance. With these arrays of issues, there is the need to find out the need to which the NASB can push for the realization of the objective of adoption of IFRS and the likely factors that can influence the full adoption of IFRS in the country. For it is a known fact that, Nigeria remains one of the countries that are yet to fully adopt the IFRS. It is expected that, the adoption of IFRS will improve the quality of corporate reporting practices and also enhance the comparability, reliability and relevancy of financial statements. Hence, in most of the accounting literatures, a number of studies have provided evidences that, adoption of international accounting standards will improve the quality of accounting information (Ashbaugh \& Pincus, 2001; Wallace \& Briston, 1993).

Furthermore, Gray (1989) opined that, accounting need to be studied in the context in which it operates in order to minimize the methodological problems of cross cultural research. Zeghal (2006) further revealed that, there is a lack of adequate research in developing international accounting standards in developing countries. Most of the researches were conducted in developed countries. Hence, an urgent need for research in developing countries in order to understand the factors that may encourage the adoption of IFRS (Zeghal, 2006). Moreover, Abdelsalam and Weetman (2003); and Zeghal and Mhedhbi (2006) is of the view that, factors which may promote the adoption of IFRS are not just one but require a multi-faceted approach. These factors may include education, external economic openness, capital size, cultural affiliation, existence of capital market and language. In line with Zeghal (2006) the need to examine some factors that may influence the full adoption of IFRS is therefore apt, considering the government proposed roadmap for the phase to phase implementation of the new standards (Ayuba, 2012; \& Madawaki, 2012). As such, this study is aimed at bridging the existing gap by focussing on government policy and company size.

\section{Review of Related Literature}

\subsection{Factors Influencing the Adoption of IFRS}

\subsubsection{Government Policy and IFRS Adoption}

The government policy of a country plays an important role in the adoption and implementation of IFRS in many developing countries (Chamisa, 2000). According to Tucker, Abdolmohammadi and Rhodes (2002) where government policy is hostile to the foreign and global principles, the adoption of IFRS may be impossible. In a similar study by
Mir and Rahaman (2005) on the adoption of international accounting standards in Bangladesh, it was found out that government policy has positive roles to play in the adoption of IFRS for the purpose of developing accounting and auditing standards. Belkaouni (2004), in a study conducted in Kazakhstan, also discovered that the government's decision has a significant role to play in the adoption of IFRS instead of Kazakhstan Accounting Standards (KAS). Joshi and Ramadhan (2002) found that government policy has a positive role to play in the adoption of IFRS in encouraging companies to follow. Government policy plays an important role in triggering the adoption of IFRS instead of using the unified accounting system in China (Xiao, 2004). This is not different in the case of Nigeria.

\subsubsection{Company Size and IFRS Adoption}

Patel (2011), conducted a study in Germany and the result showed that size of firms plays a significant role in the adoption of IFRS. Dumontier and Raffournier (1998) conducted a study on Swiss data. They showed a positive influence of company size on voluntary compliance with International Accounting Standards (IAS). The study revealed that firms which complied with IAS are larger and more internationally diversified. Chow and Wong-Boren (1987), Cooke (1989, 1991), and Meek, Roberts and Gray (1995) recognized that compliance with IFRS is positively related to company size and the company's listing status. A statistically significant relationship was also found between companies with larger turnover (medium sized companies as opposed to small companies) and the degree of readiness for the adoption of IFRS (Floropoulos \& Moschidis, 2004; Aljifri \& Khasharmeh, 2006).

It is apparent that companies listed on the stock exchange are most prepared for adopting IFRS. Similarly, medium-sized companies are more prepared than small ones. Prior studies had shown that a company's attributes such as internationality, firm size and capital need are associated with the adoption of international standards (Ashbaugh, 2001; Bradshaw \& Miller, 2004; Tarca, 2004; Hung \& Subramanyam, 2007). However, Ahmad and Nicholls (1994), Street and Gray (2002), and Glaum and Street (2003) found no significant relationship between company size and the adoption of IFRS. Ustundag et al. (2009) found that small and medium size of companies did not affect the adoption of IFRS. Ahmad and Nicholls (1994), Street and Gray (2002) and Glaum and Street (2003) findings are in contrast with the findings of (Aljifri et al., 2006; Patel, 2010) seen above.

From these studies emerges the evidence that, not all the companies could really be interested in the adoption of IFRS due to the mixed results as well as the nature of their sizes and specific finance and operating peculiarities. Besides, most of these studies are either carried out in Europe, US, Australia or the Asia axis, very few studies to our knowledge was conducted in Africa, let alone Nigeria. As such this study is aimed at bridging the gap in Nigeria and other developing countries where most of the factors 
that may influence the adoption of IFRS were not tested.

\section{Data and Methodology}

The study was designed to apply quantitative approach to data collected through the sampling survey method using a questionnaire. The statistical techniques used in this study for analyzing the data include: reliability analysis, descriptive statistics, correlation analysis and regression analysis. The total population of the listed companies active in the floor of the Nigerian Stock Exchange was 202 as of 16th August, 2013. A sample size of 132 companies was drawn from the population using Krejcie and Morgan's (1970) rule of thumb. The 132 companies were randomly drawn and the finance managers were selected from the companies as the samples and unit of analysis of this study.

\subsection{Variable Measurement}

In this study, each variable was measured with five item statement rated on a five - point Likert scale of strongly disagree, disagree, neutral, agree and strongly agree with scores from 1 to 5 as suggested by (Hair, Black, Babin \& Anderson, 2007).

\subsection{Model Specification}

The variables were combined to form a regression model, as presented in equation 1 below.

IFRS Adoption $=\beta_{0}+\beta_{2}$ GP $+\beta_{2} \mathrm{CS}+\varepsilon$

Where GP is government policy, CS is company size, $\boldsymbol{\beta}_{0}$ is the intercept, $\boldsymbol{\beta}_{1}$ to $\boldsymbol{\beta}_{2}$ are the coefficients of the explanatory variables, and $\varepsilon$ is the error term.

\section{Presentation of Result}

Table 1 as represented in the appendix shows the descriptive results of the test to examine the factors influencing the stakeholders' perception in adopting IFRS.

Company size score the highest making it the factor that most influence the adoption of IFRS (mean $=19.8917$, sd $=$ 0.4247). However, the government policy has the lowest score of the mean (mean $=19.2275$, sd $=1.12133)$. The mean of all the two factors is almost the same. This means that these factors influence the adoption of IFRS in either way.

Table 2 in the appendix, also shows the Kaiser - Meyer Oklin (KMO) that is, measurement of the sampling adequacy ranges from .511 to .842 with a significance level of .000 which is above the recommended factor loadings of 0.3 ( Hair et al., 2007).

Furthermore, Cronbach's Alpha value of each of the variables is above 0.7 . The analysis found out that the internal consistencies between the items in each case are reliable. In a nutshell, Cronbach's Alpha value is above acceptable value of 0.7 indicating that the constructs seem to have reliability as shown in Table 3 in the appendix.

The outcome of inter correlation between the variables, as shown in Table 4 in the appendix indicated that, the strength of the correlation between the variables is slightly weak and subsequently produced a small effect.

Actually, of the two variables, IFRS adoption is significantly correlated with government policy at $r=0.789$, $\mathrm{p}<0.01$ and without correlation with the company size of $(r=0.006)$ respectively. Specifically, the dependent variable (IFRS adoption) was strongly correlated with government policy, except the company size with $r=0.006$. In particular, IFRS adoption had a significant positive correlation with government policy. In terms of the independent variables, government policy showed no correlation, yet negative with company size at $r=-0.063$. In total, the result of the correlation analysis revealed that, there was a slightly fair magnitude of linear relationship among the variables of the study.

The regression results as shown in Table 5 in the appendix, on the relationship between government policy and the adoption of IFRS established a strong positive relationship between the two variables. Although studies measuring the direct relationship between government policy and the adoption of IFRS are very few; this study provides a significant relationship between government policy and the adoption of IFRS, while company size was insignificant.

\section{Results and Discussion}

The study primarily examined the perception of stakeholders on the factors that may influence the adoption of IFRS in Nigeria. As shown in Table 5, the multiple regression test performed, provided evidence concerning the relationship between government policy and the adoption of IFRS. In the first place, the statistical analysis of the data provided strong evidence indicating that stakeholders have a high perception of government policy as one of the factors that can influence the adoption of IFRS in Nigeria. The finding is in support of Xiao (2004) which revealed that government policy has an important role in triggering the adoption of IFRS instead of the using unified accounting system in China. This result is equally consistent with an earlier study conducted by Mir and Rahaman (2005) on the adoption of international accounting standards in Bangladesh. They found that, government policy had a positive role to play in the adoption of IFRS for the purpose of developing accounting and auditing standards.

Furthermore, the regression results above have proven a strong positive relationship between government policy and the adoption of IFRS. Much previous literatures had provided similar significant relationships between government policy and the adoption of IFRS. Joshi and Ramadhan (2002) found that government policy had a positive role to play in the adoption of IFRS encouraging companies to follow IFRS. In the same vein, Belkaouni 
(2004) who conducted a study in Kazakhstan, also discovered that government decisions have significant roles to play in the adoption of IFRS instead of Kazakhstan Accounting Standards. Evidence from this study suggested that, government policy plays a significant role in promoting the adoption of IFRS as perceived by the stakeholders in the country.

The result of the regression result in Table 5 indicated that company size had no significant relationship with the adoption of IFRS. The study had failed to provide a significant relationship between company size and the adoption of IFRS. Previous literatures provided significant relationships between the company size and the IFRS's adoption. However, few studies found similar results of this nature. Ahmad and Nicholls (1994), Street and Gray (2002), and Glaum and Street (2003) found no significant association between company size and the adoption of IFRS. Therefore, the finding in this study on the fact that company size was insignificant is consistent with the characteristics of Nigerian companies in relation to their size. This had a connection with why a large number of the respondents were of the view that company size does not significantly promote the adoption of IFRS in the country.

In line with the findings, the size of the companies in Nigeria has no direct bearing with whether it can influence the adoption of the standards or not because of the way the listed companies are being monitored in the country. The Nigerian government has failed to take such into consideration and also very few companies are ready to adopt the standard. A study conducted on the proposed rule - roadmap for the adoption of IFRS in Nigeria, a research based perspective on FGN, NASB \& SEC, highlighted that, standards shouldn't be imposed on the companies to adopt, rather companies should be allowed to choose either the IFRS or the NGAAP because the companies are not in the same capacity (Ayuba, 2012). Beside the issue of capabilities of companies to adopt the standards, cost benefit analysis, was also not taken into consideration.

It is apparent that, companies listed on the stock exchange were not prepared for the adoption of IFRS, which was indicated by the number of companies active in the stock exchange as at 16th August, 2013. This means that, the sets of standards are not suitable for all entities regardless of size, and this has a connection with why a large number of the respondents were not satisfied with the company size as promoting the adoption of IFRS in the country which was the repercussion of the government proposed roadmap issued by the federal government dated 28th July, 2008, on the adoption of IFRS in the country.

\section{Conclusion}

The objective of this study is to examine how factors such as government policy and company size can influence the adoption of IFRS. This study laid more emphasis on the perception of stakeholders, that is, the Nigerian listed companies, government and other relevant parties/bodies.
With regards to these objectives, an analysis of multiple-regression was fully utilized. This study provides a significant relationship between government policy and the adoption of IFRS in the country. It was found that, government policy has a positive role to play in the adoption of IFRS for the purpose of developing accounting and auditing standards. However, the study failed to provide any significant relationship between company size and the adoption of IFRS.

The study recommends that, company size should be properly taken into consideration either in terms of small, medium, and large size to ensure a smooth transition from Nigerian GAAP to full adoption of IFRS in the country.

Future research could examine these variables based on their dimension, such as Government policy (fiscal and monetary policies), Company size ( small, medium and large companies), in relation to IFRS adoption. A study on the impact of pre and post IFRS adoption, value relevance and market reaction to the adoption of IFRS could also be a good avenue for future research.

\section{Appendix A}

Table 1. Descriptive Statistics.

\begin{tabular}{cccccc}
\hline & N & Minimum & Maximum & Mean & Std. Deviation \\
\hline GP & 109 & 15.80 & 21.00 & 19.2275 & 1.12133 \\
CS & 109 & 17.80 & 21.00 & 19.8917 & .42473 \\
IFRS & 109 & 13.80 & 20.00 & 17.9853 & 1.10343 \\
\hline
\end{tabular}

Note: GP = Government Policy, $\mathrm{CS}=$ Company Size, IFRS $=$ IFRS.

Table 2. Factor analysis result.

\begin{tabular}{cccc}
\hline Variables & KMO & P - Value & Decision \\
\hline GP & .673 & .000 & valid \\
CS & .511 & .000 & valid \\
IFRS & .842 & .000 & valid \\
\hline
\end{tabular}

Note: $\mathrm{GP}=$ Government policy, $\mathrm{CS}=$ Company size, IFRS = IFRS adoption.

Table 3. Reliability test result.

\begin{tabular}{ccc}
\hline Variables & Cronbach's alpha & N of item \\
\hline GP & .711 & 5 \\
CS & .701 & 5 \\
IFRS & .899 & 5 \\
\hline
\end{tabular}

Note: GP = Government policy, $\mathrm{CS}=$ Company size, IFRS $=$ IFRS adoption.

Table4. Correlation result.

\begin{tabular}{cccc}
\hline Variable & GP & CS & IFRS \\
\hline GP & 1 & & \\
C & -.063 & 1 & 1 \\
IFRS & $.789 * *$ & .006 & 1 \\
\hline
\end{tabular}

**. Correlation is significant at the 0.01 level (2-tailed). 
Table 5. Regression result.

\begin{tabular}{ccc}
\hline Model & Sig level & \\
\hline Intercept & -1.043 & $.000^{* *}$ \\
GP & .686 & .363 \\
CS & .127 & \\
$\mathrm{~N}$ & .109 & \\
R squared & .245 & \\
Adjusted R squared & .104 & \\
\hline
\end{tabular}

** Significant at the .01 level.

\section{References}

[1] Abdelsalam, O., \& Weetman, P. (2003). Introducing international accounting standards to an emerging capital market: Relative familiarity and language effects in Egypt. Journal of International Accounting, Auditing and Taxation, $12,63-84$.

[2] Abdulkadir, M. (2012). Adoption of International Financial Reporting Standards in developing countries: The case of Nigeria. International Journal of Business and Management, 7 (3), $152-161$.

[3] Ahmed, K., \& Nicholls, D. (1994). The impact of non financial company characteristics on mandatory disclosure compliance in developing countries: The case of Bangladesh. International Journal of Accounting, 29, 62 -77.

[4] Ahmed, K., \& Nicholls, D. (1994). The impact of non financial company characteristics on mandatory disclosure compliance in developing countries: The case of Bangladesh. International Journal of Accounting, 29, 62 -77.

[5] Aljifri, K., \& Khasharmeh, H. (2006). An investigation into the suitability of the international accounting standards to the United Arab Emirates environment. International Business Review, 15, 505 - 526.

[6] Alp, A., \& Ustundag, S. (2009). Financial reporting transformation: The experience of Turkey, Critical Perspectives on Accounting, 20, 680 - 699.

[7] Ashbaugh, H. ( 2001). Non-US firms' accounting standard choices. Journal of Accounting and Public Policy, 20, 129 153.

[8] Ashbaugh, H., \& Pincus, M. (2001). Domestic accounting standards, international accounting standards, and the predictability of earnings. Journal of Accounting Research, $39(3), 417-434$.

[9] Ayuba, A.(2012). A proposed rule - roadmap for the adoption of international financial reporting standards in Nigeria: A research based perspective on FGN, NASB \& SEC. American Journal of Economics, 41- 45.

[10] Belkaoui, A. (2004). Accounting theory, 5th Ed. London: Thomson.

[11] Bradshaw, M., Bushee, B., \& Miller, G. (2004). Accounting choice, home bias, and U.S. investment in non-U.S. firms. Journal of Accounting Research , 42, 795 - 841.

[12] Chamisa, E.E. (2000). The relevance and observance of IASC standards in developing countries and the particular case of Zimbabwe. The International Journal of Accounting, $35,267-286$.
[13] Chow, C.W., \& Wong - Boreng, A. (1987). Voluntary Financial disclosure by Mexican corporations. The Accounting Review, 62(3), 533 -541.

[14] Cooke, T. E. (1989). Voluntary corporate disclosure by Swedish companies. Journal of International Financial Management and Accounting, 1(2), 171-195.

[15] Dumontier, P., \& Raffournier, B. (1998). Why firms comply voluntarily with IAS: An empirical analysis with Swiss data. Journal of International Financial Management and Accounting, 9(3), 216-245.

[16] Floropoulos, J., \& Moschidis, O. (2004) . Are the small enterprises ready for the implementation of IFRS? The case of Greece. East-West Journal of Economics and Business, 7, $81-116$.

[17] Fontes, A., Rodriques, L. L., \& Craig, R. (2005). Measuring convergence of national accounting standards with International Financial Reporting Standards. Accounting Forum, 29, 415 - 436.

[18] Glaum, M., \& Street, D. L. (2003). Compliance with the disclosure requirements of Germany's new market: IAS versus US GAAP. Journal of International Financial Management and Accounting, 14 (1), 64 - 100.

[19] Gray, S. J., Meek, G.K., \& Roberts, C. B. (1995). International capital market pressures and voluntary annual report disclosures by U.S. and U.K. multinationals. Journal of International Financial Management and Accounting, $6(1), 43-68$.

[20] Hair, J.F., Black, W.C., Babin, B.J., \& Anderson, R. E. (2010). Multivariate data analysis. A global perspective. New Jersey: Pearson Education, Inc.

[21] Hair, J.F., Money, A., Samuoel, P., \& Page, M. (2007). Research method for business. West Sunsex: John Wiley and Son Ltd.

[22] Hung, M., \& Subramanyam, K.R. (2007). Financial statement effects of adopting international accounting standards: The case of Germany. Review of Accounting Studies, 12 (4), 623 - 657.

[23] Iyoha, F.O. \& Oyerinde, D. (2010). Accounting infrastructure and accountability in the management of public expenditure in developing countries: A focus on Nigeria. Critical Perspective on Accounting, 21, 361 - 373

[24] Joshi, P.L., \& Ramadhan, S. (2002). The adoption of international accounting standards by small \& closely held companies: Evidence from Bahrain. The international journal of accounting. 37, 429 - 440.

[25] Joshi, P.L., \& Ramadhan, S. (2002). The adoption of international accounting standards by small \& closely held companies: Evidence from Bahrain. The international journal of accounting. 37, 429 - 440.

[26] Krejcie, V.R., \& Morgan, W.D. (1970). Determining sample size for research activities. Educational and Psychological Measurement, 30, 607 - 610 .

[27] Lehman, G., (2005). A critical perspective on the harmonization of accounting in a globalizing world. Critical Perspectives on Accounting, 16, 975 - 992. 
[28] Meek, G..K., Robert, C.B., \& Gray, S.J. (1995). Factors influencing voluntary annual report disclosure by US., UK., and continental European multinational corporations. Journal of International Business Studies, 26 (3), 555 - 572.

[29] Mir, M. Z., \& Rahaman, A. S. (2005). The Adoption of international accounting standards in Bangladesh. Accounting, Auditing \& Accountability Journal, 18 (6), 816-841.

[30] Neu, D. \& Ocampo, E. (2007). Doing missionary work: The World Bank and the diffusion of financial practices. Critical Perspectives on Accounting, 18 (3) 363 - 389.

[31] Okaro, S. (2004). Bank failure in Nigeria: An early warning models of corporate distress. The Nigerian Accountant, 37 (4), 23 - 33

[32] Patel, C., \& Heidhues, E. (2010). A critique of Gray's framework on accounting values using Germany as a case study. Critical Perspective on Accounting, 22, 273 - 287.

[33] Street, D. L., \& Gray S. J. (2002). Factors influencing the extent of corporate compliance with international accounting standards: Summary of a research monograph. Journal of International Accounting, Auditing and Taxation, 11, 51-76.

[34] Street, D. L., \& Gray S. J. (2002). Factors influencing the extent of corporate compliance with international accounting standards: Summary of a research monograph. Journal of International Accounting, Auditing and Taxation, 11, 51-76.

[35] Tarca, A. (2004). International convergence of accounting practices: Choosing between IAS and U.S. GAAP. Journal of International Financial Management and Accounting, 15 (1), $60-91$

[36] Tucker, R., Abdolmohammadi, M. \& Rhodes, J. (2002). The influence of accounting and auditing on a country's economic development. Review of Accounting and Finance, 1(3), 42 -53 .

[37] World Bank (2004). Report on the observance of Standards and Codes (ROSC) Nigeria, Accounting and Auditing. Retrieved 11 May, 2013, from http://www.worldbank.org/ifa/rosc aa nga.pdf.

[38] Xiao, J. Z., Weetman, P., \& Sun, M. (2004). Political influence and coexistence of a uniform accounting system and accounting standards: Recent developments in China. Abacus, 40 (2), 194 - 218.

[39] Zeghal, D., \& Mhedhbi, K. (2006).An analysis of the factors affecting the adoption of international accounting standards by developing countries. The International Journal of Accounting, 41, 373 - 386. 